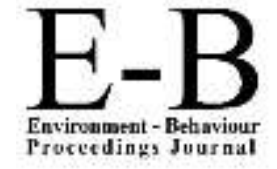

Envirodment - Behaviour
Proceeding, Juusnal

\section{AQoL2021Langkawilsland}

https://www.amerabra.org; https://fspu.uitm.edu.my/cebs; https://www.emasemasresources.com/ $5^{\text {th }}$ ABRA International Conference on Quality of Life Holiday Villa Langkawi, Langkawi Island, Malaysia, 15-16 Dec 2021

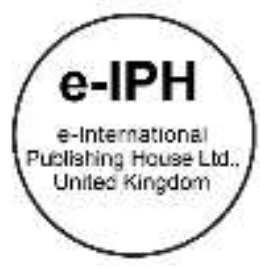

\title{
Psychological Impact and Social Support Received during COVID-19 among Nursing Students
}

\author{
Noraini Hashim¹, Norhaini Majid¹, Nurul Laili Nor Ismail1', Umi Namirah Anuar¹, Suryanto Suryanto² \\ ${ }^{1}$ Centre for Nursing Studies, Faculty of Health Sciences, Universiti Teknologi MARA, Malaysia, \\ ${ }^{2}$ School of Nursing, Faculty of Medicine, Universitas Brawijaya, Indonesia
}

hnoraini@uitm.edu.my, majidnorhaini@gmail.com, nurullailyyy14@gmail.com, uminamirah@gmail.com, suryanto.s@ub.ac.id

Tel: +60196671709

\begin{abstract}
Uncertainty of the COVID-19 outbreak impacts mental health mainly among university students. This research seeks to identify the psychological impact and social support received among nursing students in UiTM Puncak Alam during COVID-19. A cross-sectional study used Depression Anxiety Stress Scale (DASS-21) and the Impact on Social and Family Support questionnaire among 114 nursing students. Students' anxiety (2.10 \pm 1.20$)$ was higher than depression $(1.50 \pm 0.73)$. However, participants reported receiving substantial social support, especially from family members $(1.30 \pm 0.46)$. In conclusion, half of the participants showed the psychological impact; however, there was an increase in social support during the COVID-19 outbreak.
\end{abstract}

Keywords: psychological impact; social support; nursing students; COVID-19

eISSN: 2398-4287@ 2021. The Authors. Published for AMER ABRA cE-Bs by e-International Publishing House, Ltd., UK. This is an open access article under the CC BYNCND license (http://creativecommons.org/licenses/by-nc-nd/4.0/). Peer-review under responsibility of AMER (Association of Malaysian Environment-Behaviour Researchers), ABRA (Association of Behavioural Researchers on Asians/Africans/Arabians) and CE-Bs (Centre for Environment-Behaviour Studies), Faculty of Architecture, Planning \& Surveying, Universiti Teknologi MARA, Malaysia. DOI: https://doi.org/10.21834/ebpj.v6i18.3060

\subsection{Introduction}

COVID-19 is a new novel coronavirus strain. "CO" accounts for Corona, VI serves for Virus, D stands for Disease, and 19 refers to discovered diseases year (Cennimo,2021). COVID-19 impacts worldwide, not just on the education, financial but also on the psychology of a person. The World Health Organization (WHO) has issued a warning about the COVID-19 crisis' potential effect on health and social care workers' mental health. Previous pandemics involving severe acute respiratory syndrome (SARS), and Middle-East respiratory syndrome (MERS), raised worries due to the impact of several mental comorbidities, including depression, anxiety, and stress symptoms (Chua et al., 2004; Park et al., 2020).

Malaysia's first case of COVID-19 was detected on $25^{\text {th }}$ January 2020, involving 3 Chinese nationals who had close contact with an infected person in Singapore (Ministry of Health, 2021). The upbeat cases beyond 553 instances urged the Prime Minister of Malaysia to announce a Movement Control Order (MCO) to reduce the rapid spread of COVID-19 starting from 18 ${ }^{\text {th }}$ March 2020 (Prime Minister's Office of Malaysia, 2020). All the institutions were closed due to this decree, and the public were instructed to stay where they are with no social activities permitted. The closure of schools, businesses and the imposition of travel restrictions led to long-term psychological problems among communities (Van Bortel et al., 2016; Loades et al., 2020). Adolescents are also one of the groups most likely to develop high rates of depression and anxiety both before and following forced quarantine (Loades et al., 2020). Futhermore, Cao et al. (2020) found that students who live with their parents or live alone experience much higher anxiety levels.

eISSN: 2398-4287@ 2021. The Authors. Published for AMER ABRA cE-Bs by e-International Publishing House, Ltd., UK. This is an open access article under the CC BYNCND license (http://creativecommons.org/licenses/by-nc-nd/4.0/). Peer-review under responsibility of AMER (Association of Malaysian Environment-Behaviour Researchers), ABRA (Association of Behavioural Researchers on Asians/Africans/Arabians) and cE-Bs (Centre for Environment-Behaviour Studies), Faculty of Architecture, Planning \& Surveying, Universiti Teknologi MARA, Malaysia.

DOI: https://doi.org/10.21834/ebpj.v6i18.3060 


\subsection{Literature Review}

Depression statistics globally is more than 264 million people affected (WHO, 2020). During the COVID-19 outbreak, depression rates in the general population may have increased seven times (Bueno-Notivol et al., 2021). The studies also show the overall prevalence of depression was $25 \%$ in the general population compared to the global estimate of depression prevalence is from 2017, with a percentage of $3.44 \%$ (range from $2 \%$ to $6 \%$ ) (Ritchie \& Roser, 2018). In addition, the state of mental health in Malaysians two months after the outbreak of the pandemic shows there were high percentages of reported depressive (59.2\%) and anxiety (55.1\%) symptoms and stress (30.6\%) (Wong et al., 2021).

Women and those aged 18 to 24 indicated substantial levels of psychological damage (Browning et al., 2021; Yang et al., 2021). A study by Odriozola-González et al. (2020) and Wang et al. (2020) found that undergraduate students had substantial depression, anxiety, and stress level than master students. Since the state of Selangor has a significant number of COVID-19 cases, areas with the highest recorded cases of COVID-19 need to be monitored as the number of people affected by the pandemic grows tremendously. Mental health difficulties and challenges have become a major concern for everyone (Parzi \& Karim, 2021; Thapa et al., 2020).

Social support is a psychological resource available through interpersonal connections and one's social network (Kocalevent et al., 2018). A lack of social support is a well-known predictor of mental health issues (Alsubaie et al., 2019). A study by El-Zoghby et al. (2020) finds that only one-quarter of people reported receiving social support from peers (24.1\%). The study shows that the COVID-19 outbreak has had a significant psychological impact and negatively influenced social support. Since there is limited data on psychological impact and social support received during COVID-19 among health science study precisely nursing, this study aims to identify the psychological impact and social support received during the COVID-19 outbreak among nursing students in UiTM Puncak Alam. The study's objective was to determine the relationship between psychological impact and social support received during the COVID-19 outbreak among nursing students.

\subsection{Methodology}

\subsection{Study design, location and population}

A cross-sectional study was conducted at the UiTM Teknologi Mara Puncak Alam, Selangor. The study population is UiTM nursing students. The inclusion criteria are full-time nursing students in years 2, years 3, or years 4 at UiTM Puncak Alam, Selangor, and registered during March-July 2020 session. The sample size was used Raosoft Sample Size Calculator, using a confidence level of 95\%, the response distribution of $50 \%$, and the margin error of $5 \%$, giving out the recommended sample size of 112 . In addition, a simple random sampling using Online Random Generator was used to select participants who met the inclusion criteria. The study participant was UiTM students; therefore, ethical approval was received from the Research Ethics Committee Universiti Teknologi MARA REC/01/2021 (UG/MR/23).

\subsection{Instrument}

In Section A, demographic data consisted of 7 items, including gender, year of study, location during the lockdown, stay with family, parental status, household size, and family income. The participants need to select the answer based on provided chosen given. Section B, Depression Anxiety Stress Scale (DASS-21) English version questionnaire, was adapted from Lovibond \& Lovibond (1995) to measure the emotional states of depression, anxiety, and stress. DASS-21 consists of 21 -items which are 7 -items for subscale. The total scores on the DASS-21 need to be multiplied by 2 to calculate the final score. The scores from each subscale were summed up and categorised as "normal", "mild", "moderate", "severe", and "extremely severe" according to the DASS manual (Lovibond \& Lovibond,1995). Lastly, in Section C, the Impact on Social and Family Support English version questionnaire adapted from Lau et al. (2006) was used to measure family and social support changes. A Perceived Support used to rate as increased, same as before and decreased, based on five questions provided. The greater score obtained indicated participants experiencing better family and social support quality.

\subsection{Data collection}

The participants met the inclusion criteria contacted via Whatsapp to inform a detailed description of the study to be part of the study and the participant's availability to answer the questionnaire. If they agree, the google form link: https://forms.gle/iMWByAtW8DfE4FHR6 was given to the participant. The objectives of these studies are stated on the first page of the Google Form with the consent form. The submission button only can be clicked as if all the answers were completed respond by the participant. All the data answered was autosaved in google excel data in google form online. The confidentiality of the data was maintained strictly, as only re researchers could access the data

\subsection{Findings}

\subsection{Demographic Characteristics}

Respondents ( $\mathrm{n}=114$ ) agreed to participate and completely answered the questionnaires. $11.4 \%$ (13) were male respondents, and $88.6 \%$ (103) were female. $32.5 \%$ (37), 38.6\% (44), $28.9 \%$ (33) of respondents were from year 2, year 3 , and year 4 accordingly. The highest 
residential location of the respondent was from Selangor 31.6\% (36) respondents, followed by Johor, 15.8\% (18), and no respondents participated in this study from Sarawak and Perlis. Most of the respondents show that they stayed with family during COVID-19, $83.3 \%$ (95) and married parenteral status $90.4 \%$ (103). Only 10.7\% (12) respondents had 1-3 people of the household size, and almost half of respondents had 4-5 and more than 6 people in the house, in which 44.7\% (51) were in each category. More than half of respondents were from family income lower than RM2,500 per month 50.9\% (58), and the lowest was from family income more than RM10,960 per month $7.9 \%$ (9). (Refer Table 1).

Table 1 Socio-demographic characteristics of the sample $(n=114)$

\begin{tabular}{|c|c|c|c|}
\hline Variables & & $\begin{array}{l}\text { Frequency } \\
\text { (n) }\end{array}$ & $\begin{array}{l}\text { Percentage } \\
\%\end{array}$ \\
\hline \multirow[t]{2}{*}{ Gender } & Male & 13 & 11.4 \\
\hline & Female & 101 & 88.6 \\
\hline \multirow[t]{3}{*}{ Year of study } & 2 & 37 & 32.5 \\
\hline & 3 & 44 & 38.6 \\
\hline & 4 & 33 & 28.9 \\
\hline \multirow[t]{14}{*}{ Residential location } & Johor & 18 & 15.8 \\
\hline & Negeri Sembilan & 4 & 3.5 \\
\hline & Selangor & 36 & 31.6 \\
\hline & Wilayah Persekutuan KL/Putrajaya/Labuan & 3 & 2.6 \\
\hline & Melaka & 2 & 1.8 \\
\hline & Pahang & 4 & 3.5 \\
\hline & Perak & 11 & 9.6 \\
\hline & Kedah & 9 & 7.9 \\
\hline & Kelantan & 13 & 11.4 \\
\hline & Terengganu & 7 & 6.1 \\
\hline & Pulau Pinang & 4 & 3.5 \\
\hline & Perlis & 0 & 0 \\
\hline & Sabah & 3 & 2.6 \\
\hline & Sarawak & 0 & 0 \\
\hline \multirow{2}{*}{ Stay with family } & Yes & 95 & 83.3 \\
\hline & No & 19 & 16.7 \\
\hline \multirow[t]{2}{*}{ Parental status } & Married & 103 & 90.4 \\
\hline & Divorced & 11 & 9.6 \\
\hline \multirow[t]{3}{*}{ Household size } & $1-3$ & 12 & 10.5 \\
\hline & $4-5$ & 51 & 44.7 \\
\hline & More than 6 & 51 & 44.7 \\
\hline \multirow[t]{5}{*}{ Family income (RM) } & $<2500$ & 58 & 50.9 \\
\hline & $2501-3169$ & 16 & 14.0 \\
\hline & $3170-4849$ & 17 & 14.9 \\
\hline & $4850-10959$ & 14 & 12.3 \\
\hline & $>10960$ & 9 & 7.9 \\
\hline
\end{tabular}

\subsection{The Level Of Psychological Impact Among Nursing Students During The COVID-19 Outbreak}

The prevalence score of depression ranged between normal $64 \%$ (73), mild $21.9 \%$ (25) and moderate $14 \%$ (16), with an overall mean \pm SD of depression $(M=1.50, S D=0.73)$. The prevalence score of anxiety normal $48.2 \%(55)$, mild $10.5 \%(12)$, moderate $27.2 \%(31)$, severe $11.4 \%(13)$, extremely severe $2.6 \%$ (3) with overall mean $\pm S D$ of anxiety $(M=2.10, S D=1.20)$. Meanwhile, the prevalence score of stress was normal $86 \%(98)$, mild, $9.6 \%(11)$, and moderate $4.4 \%(5)$, with an overall mean \pm SD of stress $(M=1.18, S D=0.49)$. The students' anxiety was reported higher compared to depression and stress. This study concluded that the depression level of respondents as the mean 1.50 indicate fall in-between Normal and Mild categories. The anxiety level of respondents falls in between the Mild and Moderate categories (mean 2.10). The stress level of respondents was under the category Normal-Mild (mean 1.18), as shown in Table 2.

Table 2. The Psychological Impact of Nursing Students During The COVID-19 Outbreak ( $n=114$

\begin{tabular}{|c|c|c|c|c|}
\hline Variables & 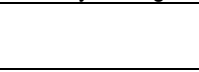 & $\begin{array}{l}\text { Frequency } \\
\text { (n) }\end{array}$ & $\begin{array}{l}\text { Percentage } \\
\%\end{array}$ & Mean \pm SD \\
\hline \multirow[t]{5}{*}{ Depression } & Normal & 73 & 64.0 & $1.50 \pm 0.73$ \\
\hline & Mild & 25 & 21.9 & \\
\hline & Moderate & 16 & 14.0 & \\
\hline & Severe & 0 & 0 & \\
\hline & Extremely severe & 0 & 0 & \\
\hline \multirow[t]{5}{*}{ Anxiety } & Normal & 55 & 48.2 & $2.10 \pm 1.20$ \\
\hline & Mild & 12 & 10.5 & \\
\hline & Moderate & 31 & 27.2 & \\
\hline & Severe & 13 & 11.4 & \\
\hline & Extremely severe & 3 & 2.6 & \\
\hline
\end{tabular}




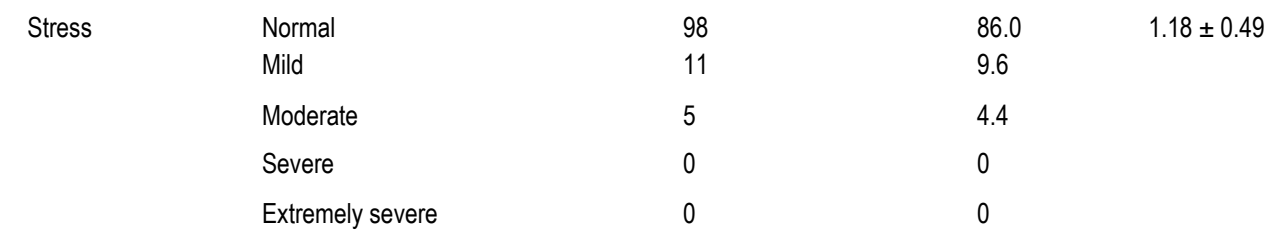

\subsection{The Level of Social Support Received During COVID-19}

$70.2 \%(80)$ respondents were becoming more caring for family members feeling during COVID-19. Table 3 shows, less than $10.5 \%$ (12) of the respondents felt a decline in social support during the COVID-19 outbreak. The average mean \pm SD of sharing of feeling with others when in the blue was reported highest $(M=1.65, S D=0.67)$ compared to the lowest, which is becoming more caring for family members feeling ( $M=1.30, S D=0.46)$. Overall, social support received increased during the COVID-19 outbreak.

Table 3. Social Support Received by Students During COVID-19 outbreak $(n=114)$

\begin{tabular}{|c|c|c|c|c|}
\hline Variables & & $\begin{array}{l}\text { Frequency } \\
\text { (n) }\end{array}$ & $\begin{array}{l}\text { Percentage } \\
\%\end{array}$ & Mean \pm SD \\
\hline Support from friends & $\begin{array}{l}\text { Increased } \\
\text { Same as before } \\
\text { Decrease }\end{array}$ & $\begin{array}{l}58 \\
51 \\
5\end{array}$ & $\begin{array}{l}50.9 \\
44.7 \\
4.4\end{array}$ & $1.54 \pm 0.58$ \\
\hline Support from family members & $\begin{array}{l}\text { Increased } \\
\text { Same as before } \\
\text { Decreased }\end{array}$ & $\begin{array}{l}74 \\
40 \\
0\end{array}$ & $\begin{array}{l}64.9 \\
35.1 \\
0\end{array}$ & $1.35 \pm 0.48$ \\
\hline $\begin{array}{l}\text { Sharing the feeling with other family } \\
\text { members }\end{array}$ & $\begin{array}{l}\text { Increased } \\
\text { Same as before } \\
\text { Decreased }\end{array}$ & $\begin{array}{l}62 \\
46 \\
6\end{array}$ & $\begin{array}{l}54.4 \\
40.4 \\
5.3\end{array}$ & $1.51 \pm 0.60$ \\
\hline $\begin{array}{l}\text { Sharing of feeling with others when in } \\
\text { the blue }\end{array}$ & $\begin{array}{l}\text { Increased } \\
\text { Same as before } \\
\text { Decreased }\end{array}$ & $\begin{array}{l}52 \\
50 \\
12\end{array}$ & $\begin{array}{l}45.6 \\
43.9 \\
10.5\end{array}$ & $1.65 \pm 0.67$ \\
\hline $\begin{array}{l}\text { Becoming more caring for family } \\
\text { members feeling }\end{array}$ & $\begin{array}{l}\text { Increased } \\
\text { Same as before } \\
\text { Decreased }\end{array}$ & $\begin{array}{l}80 \\
34 \\
0\end{array}$ & $\begin{array}{l}70.2 \\
29.8 \\
0\end{array}$ & $1.30 \pm 0.46$ \\
\hline
\end{tabular}

\subsection{The Relationship Between Psychological Impact and Social Support Received During The COVID-19 Outbreak} Table 4 shows that participants with increased social support from friends reported more to no depression $(n=42,72.4 \%)$. Meanwhile, decreased social support participants likely lead to mild to extreme depression $(n=3,60 \%)$. Therefore, there was a significant difference between depression and support from family members $\left(x^{2}(1)=5.27\right.$, $p$-value $\left.=0.02\right)$, sharing the feeling with another family member $\left(x^{2}\right.$ $(2)=9.00, p$-value $=0.01$ ), sharing a feeling with others when in blue $\left(x^{2}(2)=6.11, p=0.05\right)$, and becoming more caring for family members feeling $\left(x^{2}(1)=6.06, p\right.$-value $\left.=0.01\right)$.

Table 4 The relationship depression and social support received during the COVID-19 outbreak $(n=114)$

\begin{tabular}{|c|c|c|c|c|}
\hline \multirow[t]{2}{*}{ Variable } & \multicolumn{2}{|c|}{ Depression, $n(\%)$} & \multirow{2}{*}{$\begin{array}{l}\text { Test Statistics } \\
\text { (df) }\end{array}$} & \multirow[t]{2}{*}{$p$ value } \\
\hline & No & $\begin{array}{l}\text { Mild to extremely } \\
\text { severe }\end{array}$ & & \\
\hline Support from friends & & & $4.16(2)$ & $0.11^{b}$ \\
\hline Increased & $42(72.4)$ & $16(27.6)$ & & \\
\hline Same as before & $29(56.9)$ & $22(43.1)$ & & \\
\hline Decreased & $2(40.0)$ & $3(60.0)$ & & \\
\hline Support from family members & & & $5.27(1)$ & $0.02^{\mathrm{a}}$ \\
\hline Increased & $53(71.6)$ & $21(28.4)$ & & \\
\hline Same as before & $20(50)$ & $20(50)$ & & \\
\hline Decreased & $0(0)$ & $0(0)$ & & \\
\hline Sharing the feeling with other family & & & $9.00(2)$ & $0.01^{b}$ \\
\hline Increased & $47(75.8)$ & $15(24.2)$ & & \\
\hline Same as before & $24(52.2)$ & $22(47.8)$ & & \\
\hline Decreased & $2(33.3)$ & $4(66.7)$ & & \\
\hline $\begin{array}{l}\text { Sharing of feeling with others when in the } \\
\text { blue }\end{array}$ & & & $6.11(2)$ & $0.05^{\mathrm{a}}$ \\
\hline Increased & $39(75)$ & $13(25)$ & & \\
\hline Same as before & $29(58)$ & 21(42) & & \\
\hline Decreased & $5(41.7)$ & $7(58.3)$ & & \\
\hline $\begin{array}{l}\text { Becoming more caring for family members } \\
\text { feeling }\end{array}$ & & & $6.06(1)$ & $0.01^{a}$ \\
\hline
\end{tabular}




\begin{tabular}{cll} 
Increased & $57(71.3)$ & $23(28.7)$ \\
Same as before & $16(47.1)$ & $18(52.9)$ \\
Decreased & $0(0)$ & $0(0)$ \\
\hline aPearson Chi-Square & & \\
bFisher Exact Test & &
\end{tabular}

Table 5 shows that participants received increased social support from friends $(n=34,58.6 \%)$, family members $(n=38,51.4 \%)$ reported no anxiety during the COVID-19 outbreak. However, the participant who decreased sharing of their feeling with other family members indicates they had mild to extremely severe anxiety $(n=4,66.7 \%)$ compared to no had anxiety ( $n=2,33.3 \%$ ). Overall, only increased support from friends had a significant relationship with anxiety $p=0.04$.

Table 5. Anxiety and Social Support Received During The COVID-19 Outbreak ( $\mathrm{n}=114)$

\begin{tabular}{|c|c|c|c|c|}
\hline \multirow[t]{2}{*}{ Variable } & \multicolumn{2}{|c|}{ Anxiety, $\mathrm{n}(\%)$} & \multirow{2}{*}{$\begin{array}{l}\text { Test Statistics } \\
\text { (df) }\end{array}$} & \multirow[t]{2}{*}{$p$ value } \\
\hline & No & $\begin{array}{l}\text { Mild to extremely } \\
\text { severe }\end{array}$ & & \\
\hline Support from friends & & & $6.20(2)$ & $0.04^{b}$ \\
\hline Increased & $34(58.6)$ & 24(41.4) & & \\
\hline Same as before & $18(35.3)$ & $33(64.7)$ & & \\
\hline Decreased & $3(60.0)$ & $2(40.0)$ & & \\
\hline Support from family members & & & $0.82(1)$ & $0.37 \mathrm{a}$ \\
\hline Increased & $38(51.4)$ & $36(48.6)$ & & \\
\hline Same as before & $17(42.5)$ & $23(57.5)$ & & \\
\hline Decreased & $0(0)$ & $0(0)$ & & \\
\hline $\begin{array}{l}\text { Sharing the feeling with other family } \\
\text { members }\end{array}$ & & & $0.59(2)$ & $0.86^{b}$ \\
\hline Increased & $30(48.4)$ & $32(51.6)$ & & \\
\hline Same as before & $23(50)$ & $23(50)$ & & \\
\hline Decreased & $2(33.3)$ & $4(66.7)$ & & \\
\hline $\begin{array}{l}\text { Sharing of feeling with others when in the } \\
\text { blue }\end{array}$ & & & $3.77(2)$ & $0.15^{\mathrm{a}}$ \\
\hline Increased & $29(55.8)$ & $23(44.2)$ & & \\
\hline Same as before & $19(38.0)$ & $31(62.0)$ & & \\
\hline Decreased & $7(58.3)$ & $5(41.7)$ & & \\
\hline $\begin{array}{l}\text { Becoming more caring for family members } \\
\text { feeling }\end{array}$ & & & $0.03(1)$ & $0.87^{a}$ \\
\hline Increased & $39(48.8)$ & $41(51.2)$ & & \\
\hline Same as before & 16(47.1) & $18(52.9)$ & & \\
\hline Decreased & $0(0)$ & $0(0)$ & & \\
\hline
\end{tabular}

The study found no stress reported when receiving increased support from friends ( $n=53,91.4 \%)$ and family members $(n=66,89.2 \%)$. In addition, decreased sharing feelings with other family members $(n=5,83.3 \%)$ and their feelings with others when in blue $(n=9,75 \%)$ also indicate no stress reported. Therefore, there is no significant relationship between stress and social support $(p>0.05)$ (refer Table 6 )

Table 6. The Relationship Between Stress and Social Support Received During The COVID-19 Outbreak ( $n=114)$

\begin{tabular}{|c|c|c|c|c|}
\hline \multirow[t]{2}{*}{ Variable } & \multicolumn{2}{|c|}{ Stress, $n(\%)$} & \multirow[t]{2}{*}{ Test Statistics (df) } & \multirow[t]{2}{*}{$p$ value } \\
\hline & No & $\begin{array}{l}\text { Mild to extremely } \\
\text { severe }\end{array}$ & & \\
\hline Support from friends & & & $2.87(2)$ & $0.20^{\mathrm{b}}$ \\
\hline Increased & 53(91.4) & $5(8.6)$ & & \\
\hline Same as before & $41(80.4)$ & $10(19.6)$ & & \\
\hline Decreased & $4(80.0)$ & $1(20.0)$ & & \\
\hline Support from family members & & & $1.82(1)$ & $0.18^{a}$ \\
\hline Increased & $66(89.2)$ & $8(10.8)$ & & \\
\hline Same as before & $32(80.0)$ & $8(20)$ & & \\
\hline Decreased & $0(0)$ & $0(0)$ & & \\
\hline $\begin{array}{l}\text { Sharing the feeling with other family } \\
\text { members }\end{array}$ & & & $4.13(2)$ & $0.13^{a}$ \\
\hline Increased & $57(91.9)$ & $5(8.1)$ & & \\
\hline Same as before & $36(78.3)$ & $10(21.7)$ & & \\
\hline Decreased & $5(83.3)$ & $1(16.7)$ & & \\
\hline $\begin{array}{l}\text { Sharing of feeling with others when in the } \\
\text { blue }\end{array}$ & & & $2.20(2)$ & $0.33^{a}$ \\
\hline Increased & $47(90.4)$ & $5(9.6)$ & & \\
\hline Same as before & $42(84.0)$ & $8(16)$ & & \\
\hline Decreased & $9(75)$ & $3(25)$ & & \\
\hline $\begin{array}{l}\text { Becoming more caring for family members } \\
\text { feeling }\end{array}$ & & & $0.52(1)$ & $0.56^{\mathrm{b}}$ \\
\hline Increased & $70(87.5)$ & $10(12.5)$ & & \\
\hline
\end{tabular}




\begin{tabular}{lll} 
Same as before & $28(82.4)$ & $6(17.6)$ \\
Decreased & $0(0)$ & $0(0)$ \\
\hline & & aPearson Chi-Square \\
& bFisher Exact Test
\end{tabular}

\subsection{The Relationship Between Year of Study and Depression}

When the difference was compared between the year of study and level of depression, participants in year 2 had mild to extremely severe depression $(n=19,48.6 \%)$ than the participant in year $4,(n=13,39.4 \%)$. Therefore, there is a marginally significant relationship between the year of study with depression $x^{2}(2)=6.10, p=0.05$

Table 7.Year of Study and Depression During COVID-19 $(n=114)$

\begin{tabular}{|c|c|c|c|c|}
\hline \multirow[t]{2}{*}{ Variable } & \multicolumn{2}{|c|}{ Depression, $n(\%)$} & \multirow[t]{2}{*}{$x^{2}(d f)$} & \multirow[t]{2}{*}{$p$ value } \\
\hline & No & $\begin{array}{l}\text { Mild to extremely } \\
\text { severe }\end{array}$ & & \\
\hline Year of study & & & $6.10(2)$ & 0.05 \\
\hline Year 2 & 19(51.4) & $18(48.6)$ & & \\
\hline Year 3 & $34(77.3)$ & $10(22.7)$ & & \\
\hline Year 4 & $20(60.6)$ & $13(39.4)$ & & \\
\hline
\end{tabular}

\subsection{Discussion}

\subsection{Psychological Impact Among Nursing Students During The COVID-19 Outbreak}

The level of psychological impact among nursing students indicates that more than half of the participants have depression, anxiety and stress. This result is comparable with one study's findings in Malaysia by Faez et al. in 2020 using the same scale where 64.94\%, 67.21\%, and $59.29 \%$ of the participants reported depression, anxiety, and anxiety, and stress, respectively. A study by Ghazawy et al. (2020) during May 2020 also found that $70.5 \%, 53.6 \%$, and $47.8 \%$ of Egyptian students, respectively, suffered from depression, anxiety, and stress. Another study by Odriozola-González et al., (2020) in March 2020 found 2530 respondents were showed moderate to severe depressions, anxiety, and stress scores by $34.19 \%, 21.34 \%$, and $28.14 \%$, respectively. The score of depression and stress was reported higher in the previous study because of the timeline conducted. The previous research was conducted within 1-5 months of the WHO announced public health emergency where the impact and effect are apparent. However, this study found the anxiety was higher compared to the previous study. This shows that the longer duration of the COVID-19 outbreaks, people's anxiety increases. Thus in the future, to overcome psychological impact during quarantine, social support such as an online counselling strategy could be beneficial to lessen students psychological problems.

\subsection{Social Support Received By Nursing Students During COVID-19 Outbreak}

The social support received by nursing students in UiTM Puncak Alam during COVID-19 raise among friends and family. They also regularly communicate their feelings with family members and have been known to share feelings with people out of the blue. As a result, the sensation of becoming more caring for family members has grown. Previous studies also supported this result, finding where social support increased during the outbreak (El-Zoghby et al.,2020; Liu \& Wang, 2021). Furthermore, other studies conducted by Loades et al. (2020) also indicate that the sluggish progress of the outbreak causes individuals to bond and seek support. Therefore, the effect of COVID-19 strengthens most of the nursing students' social support system needed during the outbreak.

\subsection{The Relationship of Psychological Impact Among Nursing Students and The Social Support}

This study revealed a significant relationship between depression and social support. It shows that increased support from a family member and others will suppress their depression level. A study on the Effect of Social Support on Mental Health in Chinese Adolescents During the Outbreak of COVID-19 by Qi et al. (2020) reveals that only teenagers with medium and low levels of social support had a greater incidence of mental health issues. Frontline employees, or the organisations they worked for, were unaware of the resources available to help them maintain their mental health (Pollock et al., 2020). They were also relatively confident in having effective formal and informal communication, giving positive, safe, and supportive learning environments for frontline staff. This study is similar to the previous finding that increased social support suppresses their depression. This is because communication will make some feel at ease as effective communication builds trust, prevents and resolves someone's problem, and may provide them direction and clarification (CLIMB, 2019).

\subsection{The Relationship of The Year of Study and Depression Among Nursing Students During COVID-19 Outbreak}

There is a marginally significant association between depression and the year of study. Similarly, depression among students was linked to uncertainty about their grades and suddenly overwhelming academic online tasks and sessions, which contributed to the onset of COVID-19 (Hamaideh et al., 2021). Furthermore, Sahu (2020) and Yang et al., (2021) highlighted the closures of universities due to the COVID-19 interrupting college students' learning process. As a result of the institution's closure, which forces the online learning process, students are easily depressed by the tasks assigned according to the core subjects in each year of study. Thus, a further step must be taken to create awareness among academicians that academic workload and separation from the university during COVID-19 negatively affected student depression. 


\subsection{Conclusion \& Recommendations}

In conclusion, this study reveals that more than half of the participants show the psychological impact during COVID-19. Although there is a psychological impact, there was an increase in social support received during the outbreak. The best approach to deal with the psychological effects of COVID-19 is to get advice from a professional. An increase in social support also can alter mental health. As a limitation of the study, DASS-21 is a screening tool to identify depression, stress and anxiety. In the future, another psychological test should be used together with DASS to measure possible mental illness that may occur for participants who had severe depression, stress, and anxiety. Furthermore, since COVID-19 is nowhere to be seen in the end, the factor affecting the students' psychological needs to be identified to reduce psychological impact. Therefore, the universities need to pay special attention to those students battling psychological impact cause this situation might worsen if left untreated. This finding suggested in the future, to overcome psychological impact during quarantine, social support such as an online counselling strategy could be beneficial to lessen students' psychological problems.

\section{Acknowledgement}

The authors would like to thank Universiti Teknologi MARA, Centre for Nursing Studies, Faculty of Health Sciences Universiti Teknologi MARA, Campus Puncak Alam and all respondents who participated in this study

\section{Paper contribution to Related Field of Study}

The result of this study raises awareness of the psychological impact of COVID-19 on nursing students. In addition, perhaps the outcome of this study could support developing online counselling strategies to minimise the psychological effect during the COVID-19 outbreak.

\section{References}

Alsubaie, M. M., Stain, H. J., Webster, L. A. D., \& Wadman, R. (2019). The role of sources of social support on depression and quality of life for university students. Http://Mc.Manuscriptcentral.Com/Rady, 24(4), 484-496. https://doi.org/10.1080/02673843.2019.1568887

Browning, M. H. E. M., Larson, L. R., Sharaievska, I., Rigolon, A., McAnirlin, O., Mullenbach, L., Cloutier, S., Vu, T. M., Thomsen, J., Reigner, N., Metcalf, E. C., D’Antonio, A., Helbich, M., Bratman, G. N., \& Alvarez, H. O. (2021). Psychological impacts from COVID-19 among university students: Risk factors across seven states in the United States. PLOS ONE, 16(1), e0245327. https://doi.org/10.1371/JOURNAL.PONE.0245327

Bueno-Notivol, J., Gracia-García, P., Olaya, B., Lasheras, I., López-Antón, R., \& Santabárbara, J. (2021). Prevalence of depression during the COVID-19 outbreak: A meta analysis of community-based studies. International Journal of Clinical and Health Psychology, 21(1). https://doi.org/10.1016/j.jichp.2020.07.007

Cao, W., Fang, Z., Hou, G., Han, M., Xu, X., Dong, J., \& Zheng, J. (2020). The psychological impact of the COVID-19 epidemic on college students in China. Psychiatry Research, 287, 112934. https://doi.org/10.1016/j.psychres.2020.112934

Cennimo. J, D. (2021). What is COVID-19?. Retrieved 24 December 2021, from https://www.medscape.com/answers/2500114-197401/what-is-covid-19 Chua, S. E., Cheung, V., Cheung, C., Mcalonan, G. M., Wong, J. W., Cheung, E. P., Chan, M. T., Wong, M. M., Tang, S. W., Choy, K. M., Wong, M. K., Chu, C. M., \& Tsang,

K. W. (2004). Psychological Effects of the SARS Outbreak in Hong Kong on High-Risk Health Care Workers. In Can J Psychiatry (Vol. 49, Issue 6). http://content.nejm.org/cgi/reprint/

CLIMB Professional Development and Training. (2019, July 09). The 7 Benefits of Effective Communication in Personal and Professional Settings. Portland Community College. https://climb.pcc.edu/blog/the-7-benefits-of-effective-communication-in-personal-and-professional-settings

El-Zoghby, S. M., Soltan, E. M., \& Salama, H. M. (2020). Impact of the COVID-19 Pandemic on Mental Health and Social Support among Adult Egyptians. Journal of Community Health, 45(4), 689-695. https://doi.org/10.1007/s10900-020-00853-5

Faez, M., Hadi, J., Abdalqader, M., Assem, H., Ads, H. O., \& Ghazi, H. F. (2020). Impact of lockdown due to covid-19 on mental health among students in private university at selangor. European Journal of Molecular and Clinical Medicine, 508-517.

Ghazawy, ER., AA, E., EM, M., DM, K., A, A., Z, M., EF, M., EE, H., S, A. H., SA, E., \& AES, M. (2020). Psychological impacts of COVID-19 pandemic on the university students in Egypt. Health Promotion International. https://doi.org/10.1093/HEAPRO/DAAA147

Hamaideh, S. H., Al-Modallal, H., Tanash, M., \& Hamdan-Mansour, A. (2021). Depression, anxiety and stress among undergraduate students during COVID-19 outbreak and "home-quarantine." Nursing Open. https://doi.org/10.1002/nop2.918

Hassan, H. (2020, February 3). Wuhan virus: Malaysia confirms 4 cases, 3 patients related to Singapore's first confirmed case. The Straits Times. https://www.straitstimes.com/asia/se-asia/malaysia-confirms-first-cases-of-wuhan-coronavirus-infection

Kocalevent, R.-D., Berg, L., Beutel, M. E., Hinz, A., Zenger, M., Härter, M., Nater, U., \& Brähler, E. (2018). Social support in the general population: standardization of the Oslo social support scale (OSSS-3). BMC Psychology 2018 6:1, 6(1), 1-8. https://doi.org/10.1186/S40359-018-0249-9

Liu, Q., \& Wang, Z. (2021). Perceived stress of the COVID-19 pandemic and adolescents' depression symptoms: The moderating role of character strengths. https://doi.org/10.1016/j.paid.2021.111062

Loades, M. E., Chatburn, E., Higson-Sweeney, N., Reynolds, S., Shafran, R., Brigden, A., Linney, C., McManus, M. N., Borwick, C., \& Crawley, E. (2020). Rapid Systematic 
Review: The Impact of Social Isolation and Loneliness on the Mental Health of Children and Adolescents in the Context of COVID-19. In Journal of the American Academy of Child and Adolescent Psychiatry (Vol. 59, Issue 11, pp. 1218-1239.e3). Elsevier Inc. https://doi.org/10.1016/j.jaac.2020.05.009

Lovibond, S. H., \& Lovibond, P. F. (1995). Manual for the Depression Anxiety Stress Scales. In Psychology Foundation of Australia (Vol. 56).

Ministry of Health (2021). COVID-19 Malaysia. http://covid-19.moh.gov.my/terkini-negeri/page:3

Odriozola-González, P., Planchuelo-Gómez, Á., Irurtia, M. J., \& de Luis-García, R. (2020). Psychological effects of the COVID-19 outbreak and lockdown among students and workers of a Spanish university. Psychiatry Research, 290. https://doi.org/10.1016/j.psychres.2020.113108

Park, H. Y., Park, W. B., Lee, S. H., Kim, J. L., Lee, J. J., Lee, H., \& Shin, H. S. (2020). Posttraumatic stress disorder and depression of survivors 12 months after the outbreak of Middle East respiratory syndrome in South Korea. BMC Public Health, 20(1). https://doi.org/10.1186/s12889-020-08726-1

Parzi, M. N., \& Karim, L. A. (2021). 800,000 hilang kerja sejak COVID-19 melanda . BHOnline. https://www.bharian.com.my/berita/nasional/2020/10/748412/800000-hilangkerja-sejak-covid-19-melanda

Pollock, A., Campbell, P., Cheyne, J., Cowie, J., Davis, B., McCallum, J., McGill, K., Elders, A., Hagen, S., McClurg, D., Torrens, C., \& Maxwell, M. (2020). Interventions to support the resilience and mental health of frontline health and social care professionals during and after a disease outbreak, epidemic or pandemic: a mixed methods systematic review. Cochrane Database of Systematic Reviews, 2020(11). https://doi.org/10.1002/14651858.CD013779

Prime Minister's Office of Malaysia. (2020). https://www.pmo.gov.my/2020/03/perutusan-khas-yab-perdana-menteri-mengenai-covid-19-16-mac-2020/

Qi, M., Zhou, S. J., Guo, Z. C., Zhang, L. G., Min, H. J., Li, X. M., \& Chen, J. X. (2020). The Effect of Social Support on Mental Health in Chinese Adolescents During the Outbreak of COVID-19. Journal of Adolescent Health, 67(4), 514-518. https://doi.org/10.1016/J.JADOHEALTH.2020.07.001

Ritchie, H., Roser, M. (2018). Mental Health. Our World in Data. Retrieved from https://ourworldindata.org/mental-health.

Sahu, P. (2020). Closure of Universities Due to Coronavirus Disease 2019 (COVID-19): Impact on Education and Mental Health of Students and Academic Staff. https://doi.org/10.7759/cureus.7541

Thapa, B., Gita, S., Chatterjee, K., \& Devrani, A. (2020). Impact of COVID-19 on the Mental Health of the Society \& HCW (Healthcare workers): A Systematic Review. In International Journal of Science and Healthcare Research (www.ijshr.com) (Vol. 5, Issue 2). www.ijshr.com

Van Bortel, T., Basnayake, A., Wurie, F., Jambai, M., Koroma, A. S., Muana, A. T., Hann, K., Eaton, J., Martin, S., \& Nellums, L. B. (2016). Psychosocial effects of an Ebola outbreak at individual, community and international levels. Bulletin of the World Health Organization, 94(3). https://doi.org/10.2471/blt.15.158543

Yang, C., Chen, A., \& Chen, Y. (2021). College students' stress and health in the COVID-19 pandemic: The role of academic workload, separation from school, and fears of contagion. PLOS ONE, 16(2). https://doi.org/10.1371/journal.pone.0246676

Wang, C., Tee, M., Roy, A. E., Fardin, M. A., Srichokchatchawan, W., Habib, H. A., Tran, B. X., Hussain, S., Hoang, M. T., Le, X. T., Ma, W., Pham, H. Q., Shirazi, M., Taneepanichskul, N., Tan, Y., Tee, C., Xu, L., Xu, Z., Vu, G. T., ... Kuruchittham, V. (2021). The impact of COVID-19 pandemic on physical and mental health of Asians: A study of seven middle-income countries in Asia. PLOS ONE, 16(2 Febuary). https://doi.org/10.1371/journal.pone.0246824

Wong, L. P., Alias, H., Md Fuzi, A. A., Omar, I. S., Nor, A. M., Tan, M. P., Baranovich, D. L., Saari, C. Z., Hamzah, S. H., Cheong, K. W., Poon, C. H., Ramoo, V., Che, C. C., Myint, K., Zainuddin, S., \& Chung, I. (2021). Escalating progression of mental health disorders during the COVID-19 pandemic: Evidence from a nationwide survey. PLoS ONE, 16(3 March), 1-14. https://doi.org/10.1371/journal.pone.0248916

World Health Organisation. (2020). https://www.who.int/westernpacific/health-topics/detail/coronavirus 